\title{
Irrigation and Household Water Test and Interpretation ${ }^{1}$
}

Rao Mylavarapu ${ }^{2}$

\section{Purpose}

Analytical tests for samples of water from sources, usually wells, intended for irrigation and/or household usage are offered through the University of Florida/IFAS Extension Soil Testing Laboratory (ESTL) in Gainesville. The tests offered only help diagnose potential problems in the pipelines and plumbing. The ESTL does not test for suitability of the water for human consumption. Test for bacteria and other contaminants with regards to human consumption may be available from your County Health Department or from selected commercial laboratories.

\section{Specific tests conducted}

Water samples are tested for physical and chemical properties to show potential current or future problems in the water and plumbing pipelines. Table 1 lists analyses for the respective problems that are part of a routine water test at the ESTL.
Table 1.

\begin{tabular}{|c|c|c|}
\hline \multirow[t]{2}{*}{ Tests } & \multicolumn{2}{|c|}{ Potential Problems } \\
\hline & $\begin{array}{c}\text { Irrigation } \\
\text { (including } \\
\text { micro-irrigation) }\end{array}$ & Household \\
\hline $\begin{array}{l}\mathrm{Ca}, \mathrm{Mg} \& \\
\text { Total } \\
\text { Carbonates }\end{array}$ & $\begin{array}{l}\text { Liming } \\
\text { potential/ } \\
\text { plugging }\end{array}$ & Hardness \\
\hline $\mathrm{Fe} \& \mathrm{Mn}$ & $\begin{array}{l}\text { Foliage } \\
\text { stains/plugging } \\
\text { problems }\end{array}$ & Staining and taste \\
\hline $\mathrm{Na} \& \mathrm{Cl}$ & $\begin{array}{l}\text { Salt water } \\
\text { intrusion, plant } \\
\text { damage }\end{array}$ & $\begin{array}{l}\text { Salt water } \\
\text { intrusion \& } \\
\text { Landscape plant } \\
\text { damage }\end{array}$ \\
\hline $\begin{array}{l}\text { Electrical } \\
\text { Conductivity } \\
\text { (dissolved } \\
\text { salts) }\end{array}$ & $\begin{array}{l}\text { Plant damage } \\
\text { from high salt } \\
\text { content }\end{array}$ & $\begin{array}{l}\text { Plant damage } \\
\text { from high salt } \\
\text { content }\end{array}$ \\
\hline $\mathrm{pH}$ & $\begin{array}{l}\text { Metal pipeline } \\
\text { corrosion and/or } \\
\text { plugging }\end{array}$ & Corrosion \\
\hline $\begin{array}{l}\text { Suspended } \\
\text { solids }\end{array}$ & Plugging & Plugging \\
\hline
\end{tabular}

1. This document is SL219, a fact sheet of the Soil and Water Science Department, Florida Cooperative Extension Service, Institute of Food and Agricultural Sciences, University of Florida. Original publication date October 2004. Visit the EDIS Web Site at http://edis.ifas.ufl.edu.

2. Rao S. Mylavarapu, Assistant Professor, Extension Soil and Nutrient Management Specialist, and Director of Extension Soil Testing Laboratory, Soil and Water Science Department, Cooperative Extension Service, Institute of Food and Agricultural Sciences, University of Florida, Gainesville, $32611-0290$.

The Institute of Food and Agricultural Sciences (IFAS) is an Equal Employment Opportunity - Affirmative Action Employer authorized to provide research, educational information and other services only to individuals and institutions that function without regard to race, creed, color, religion, age, disability, sex, sexual orientation, marital status, national origin, political opinions or affiliations. For information on obtaining other extension publications, contact your county Cooperative Extension Service office. Florida Cooperative Extension Service//nstitute of Food and Agricultural Sciences / University of Florida / Larry R. Arrington, Interim Dean 


\section{Sample Submission}

The ESTL requires at least a pint of water when sample is submitted for analysis collected in a plastic bottle. Glass bottles are NOT recommended for sample collection and submission. Also the plastic bottle intended for water sample collection and submission should NOT be cleaned with soap or detergent. The sample(s) should be carefully packed to prevent leakage or damage during postal transit. Corrugated shipping boxes (generally used for shipping soil samples) are available free-of-cost at your local county extension office and can be used when mailing water samples.

Samples submitted for a water test should be accompanied by a properly filled-out ESTL Water Test Information Sheet (SL-133), available at your local county extension office, on EDIS (http://edis.ifas.ufl.edu/SS184), or through the ESTL web site (http://soilslab.ifas.ufl.edu).

Appropriate fee(s) for the test should be enclosed along with the sample(s). The fee schedule for various testing services at the ESTL is published at the above web site or can be obtained from your local county extension office.

\section{Collecting a Water Sample}

It is very important to allow the water to run for several minutes from the intended source before collection. Such free flow will help flush any standing water in the pipelines, particularly for household samples and ensure that a collected sample is indeed directly from the well. Water that has been standing in the house plumbing for some time is not a representative sample.

In case of irrigation water samples, either regular or micro-irrigation, sampling should be done at a point closest to the water source, prior to filtering or any other device if used, so that the sample collected represents the water source and is not affected unduly by a lengthy pipeline in between.

The sample container and the lid should be rinsed several times in the flowing water; however soap or detergent should NOT be used. After rinsing, the container should be filled with flowing water completely without any air space. The container should be closed tightly with the lid to prevent any leakage.

\section{Report of Water Test Results}

The reported values have different meanings depending upon the planned uses of the water. The following interpretations are divided into Household Uses and Irrigation sections. Please read the applicable section to better understand these water test results.

\section{Household Uses Interpretations}

The physical and chemical determinations made by the Extension Soil Testing Laboratory can be effectively used to diagnose potential problems in water.

- Hardness is calculated according to the following equation:

Hardness (parts per million, $\mathrm{ppm})=(\mathrm{ppm} \mathrm{Ca}$ x 2.5) + (ppm Mg x 4.1)

Table 2 will assist in classification of water hardness.

Table 2.

\begin{tabular}{|l|c|c|}
\hline \hline \multirow{2}{*}{ Interpretation } & \multicolumn{2}{|c|}{ Hardness } \\
\cline { 2 - 3 } & ppm & grains per gallon \\
\hline soft & $0-17$ & $0-1$ \\
relatively soft & $17-50$ & $1-3$ \\
moderately hard & $50-120$ & $3-7$ \\
hard & $120-170$ & $7-10$ \\
very hard & $>170$ & $>10$ \\
\hline \hline
\end{tabular}

- Iron and Mn can impart a metallic taste to water as well as stain clothes and plumbing fixtures. Staining can be caused by as little as 0.3 ppm Fe or Mn.

- Electrical Conductivity of water is related to the amount of dissolved salts in the water. Higher salinity results in higher electrical conductivity. Increases in electrical conductivity with time may mean that the aquifer is turning brackish or that salt water intrusion is occurring. 
- Sodium and Chloride levels are used to define the type of salts contributing to the electrical conductivity of the water. Electrical conductivity measures the presence of all dissolved salts. If the electrical conductivity reading is elevated, the presence of sodium and chloride indicates that the water source is brackish or that salt water may have intruded into the water source.

- $\mathbf{p H}$ is a measurement which determines the level of acidity of the water. The $\mathrm{pH}$ of water can change rapidly for a number of reasons. If the reading is lower than 6.5 , treatment of water may be necessary to preclude damage to metallic plumbing.

Additional information on interpretation of these results can be found in IFAS Circular 703, Home Water Quality and Safety (http://edis.ifas.ufl.edu/AE009).

\section{Irrigation and Microirrigation Interpretations}

Interpretation of water quality for irrigation purposes must be crop-specific. Crops respond differently to the quality of water with which they are irrigated. Use the following information as a guideline to determine if a possible problem exists. If there is a possible problem indicated, consult with your county extension agent and/or refer to the additional publications cited in the following text.

- $\mathbf{p H}$ is a measurement which determines made the level of the acidity or alkalinity of the water. Much of the Florida's well waters are alkaline ( $\mathrm{pH} 7.6$ to 8.5 ). The high $\mathrm{pH}$ results from the calcium carbonate aquifer in which the water has been in contact. Use of such water in effect causes liming of the crop. Some crops, blueberry or pine seedlings will grow poorly if exposed to water containing appreciable amounts of lime. Surface waters are usually lower in $\mathrm{pH}$.

- Electrical conductivity of water is related to the amount of dissolved salts in the water. Higher salinity results in higher electrical conductivity. As the electrical conductivity increases, the plant must expend more energy to take in nutrients dissolved in the water from fertilizer and the soil. Some plants are very sensitive to salinity, while others can tolerate a wide range. Use Table 3 to make general interpretations.

Table 3.

\begin{tabular}{|l|c|}
\hline \hline \multirow{2}{*}{ Class of water } & Electrical Conductivity \\
\cline { 2 - 3 } & $\mathbf{d S} / \mathbf{m}$ or $\mathbf{~ m h o s} / \mathbf{c m}^{*}$ \\
\hline Excellent & 0.25 \\
Good & $0.25-0.75$ \\
Permissible & $0.75-2.00$ \\
Doubtful & $2.00-3.00$ \\
Unsuitable & $>3.00$ \\
\hline \multicolumn{2}{|c}{ "ppm soluble salts $=\mathrm{EC} \times 700$} \\
\hline \hline
\end{tabular}

- Total Carbonates and Bicarbonates are a direct measure of the liming potential of the water. For many crops, use of water with an appreciable liming potential is not of concern and may lower the need for agricultural lime additions. However, as noted above, some crops will be adversely affected. Neutralization of the liming potential can be economically accomplished in some situations by treatment of water with acid. Refer to IFAS fact sheet SL142, Neutralizing Excess Bicarbonates from Irrigation Water (http://edis.ifas.ufl.edu/SS165).

- Ca and Mg are used to calculate Hardness described in the Household Uses described above.

- Na and $\mathbf{C l}$ can be used to determine the type of salts present and to diagnose the possibility of saltwater intrusion.

- Fe and Mn can cause plant tissue staining. Overhead irrigation with water containing levels above 0.3 ppm may cause staining to foliage. Additionally such levels indicate that the water should be treated to prevent micro-irrigation plugging due to enhanced microbial growth or iron encrustations. Table 4 lists criteria for estimating plugging potential of micro-irrigation water sources. 
Table 4.

\begin{tabular}{|l|c|c|c|c|}
\hline \hline \multicolumn{5}{|c|}{ Plugging Potential } \\
\cline { 1 - 3 } \multicolumn{1}{c|}{ Factor } & Units & Slight & Moderate & Severe \\
\hline $\mathrm{pH}$ & & 7.0 & $7.0-7.5$ & 7.5 \\
$\begin{array}{l}\text { Suspend. } \\
\text { solids }\end{array}$ & $\mathrm{ppm}$ & 50 & $50-100$ & 100 \\
$\mathrm{Mn}, \mathrm{Fe}$ & $\mathrm{ppm}$ & 0.1 & $0.1-1.5$ & 1.5 \\
Hardness & $\mathrm{ppm}$ & 150 & $150-300$ & 300 \\
Electrical & $\mathrm{dS} / \mathrm{m}$ & 0.7 & $0.7-2.9$ & 2.9 \\
Conduct. & & & & \\
\hline \hline
\end{tabular}

- Suspended solids are used to predict the amount of undissolved material that is in the water. High levels of suspended solids content indicates that plugging problems are likely to occur if the water is used for micro-irrigation without adequate filtration. See Table 4. 